\title{
Associations between seabirds and subsurface predators around Oahu, Hawaii
}

\author{
Aaron J. Hebshi ${ }^{1, *}$, David C. Duffy ${ }^{2}$, K. David Hyrenbach ${ }^{3}$ \\ ${ }^{1}$ Department of Zoology, and ${ }^{2}$ Department of Botany, University of Hawaii, Manoa, Honolulu, Hawaii 96822, USA \\ ${ }^{3}$ Department of Marine Science, Hawaii Pacific University, Kaneohe, Hawaii 96744, USA
}

\begin{abstract}
Many species of tropical seabirds rely on subsurface predators such as tuna and dolphins to drive prey close to the ocean's surface. We observed seabird foraging events from fishing vessels around the island of Oahu, Hawaii, to determine the prevalence and relative importance of different subsurface predators to seabird foraging. Sixty-nine seabird foraging events were observed, in 62 of which the presence and/or identity of subsurface predators could be determined. Of those 62, all but two involved subsurface predators and accounted for $99.8 \%$ of all foraging birds. Skipjack tuna Katsuwonus pelamis were the predominant (81\%) subsurface predator involved in seabird feeding events, with odontocetes Stenella attenuata and Pseudorca crassidens (8\%), mahimahi Coryphaena hippurus (6\%), and yellowfin tuna Thunnus albacares $(2 \%)$ being less common. Wedgetailed shearwaters Puffinus pacificus and brown noddies Anous stolidus foraged in association with tuna schools more often than would be expected by chance alone. Red-footed boobies Sula sula, in contrast, did not associate with any subsurface predator in greater proportion than what would be expected by chance. Nine additional seabird species were observed foraging in association with subsurface predators, but not in numbers large enough for statistical analysis. This study highlights the value of regional investigations able to uncover the variable nature of seabird-subsurface-predator associations. The finding that, in Hawaii, at least 2 species of seabirds showed tight dependence on tuna underlines the need for tuna fishery management to address the potential indirect ecological effects of fishing.
\end{abstract}

KEY WORDS: Tropical seabirds - Subsurface predators - Skipjack tuna - Katsuwonus pelamis · Wedge-tailed shearwater $\cdot$ Puffinus pacificus $\cdot$ Hawaii $\cdot$ Pacific Ocean

\section{INTRODUCTION}

Uncovering the strength of interspecific relationships is a main thrust of ecological research, particularly when it is necessary to predict the ecosystemwide ramifications of changes in the abundance or distribution of a given species (Krebs 1972). For example, the often-surprising trophic cascades caused by the removal or addition of one species illustrate the importance of tight ecological relationships to ecosystem structure (e.g. Estes et al. 2004, Myers et al. 2007). While predators in tropical pelagic systems have generally been found to be highly catholic in their diets (e.g. Harrison et al. 1983, Kitchell et al. 1999, Potier et al. 2007), there is mounting evidence of tight inter- specific associations involving oceanic birds and subsurface predators (cetaceans, large predatory fishes, sea turtles) (e.g. Au 1991, Pitman \& Ballance 1992, Pitman 1993). These subsurface predators make prey available to the birds by driving and concentrating prey close to the ocean's surface, thus enhancing the foraging opportunities of surface-feeding and shallowdiving birds (Ashmole 1971). Because tuna, in particular, are harvested at such high global levels (5.1 million tons in 2005; FAO 2007), changes in their abundance and distribution may affect the foraging success of the associated seabirds.

If foraging opportunities were to become more sparse, that may further impair foraging success of the associated seabirds because of the tendency of sea- 
birds to use each other to find prey patches, a process termed local enhancement (Grünbaum \& Veit 2003). A critical first step to assess these potential impacts is to quantify the degree of reliance of seabirds on tuna and other subsurface predators.

Previous research has shown that the composition of the seabird assemblages associated with subsurface predators varies geographically, and that even within a given region, these associations may vary depending on the ecological setting and the species involved. In Hawaii, Harrison \& Seki (1987) found that most (75\%) foraging seabird flocks occurred over schools of skipjack tuna Katsuwonus pelamis. In the eastern tropical Pacific (ETP), Au \& Pitman $(1986,1988)$ documented tight associations between several seabird species (terns, shearwaters, boobies, frigatebirds, petrels) and yellowfin tuna Thunnus albacares and spotted Stenella attenuata and spinner Stenella longirostris dolphins. Yet, while frigatebirds and sooty terns Sterna fuscata were obligate commensals with these subsurface predators, other species were more facultative. For instance, the shearwaters and petrels were often observed feeding on free-floating organisms away from subsurface predators (Au \& Pitman 1988).

Ballance et al. (1997) expanded this analysis by documenting the influence of ocean productivity structuring the composition of seabird flocks associated with subsurface-predator schools in the ETP. Booby flocks predominated in high-productivity waters, flocks of wedge-tailed shearwater Puffinus pacificus and Juan Fernández petrel Pterodroma externa occurred in intermediate-productivity waters, and sooty tern flocks inhabited low-productivity waters. Several recent studies in other ocean basins have underscored the widespread incidence and regional variability in seabird-subsurface-predator associations. Off the Azores Islands (eastern Atlantic Ocean), Clua \& Grosvalet (2001) documented that several species of dolphin, and occasionally large tuna, provide foraging opportunities for shearwaters. In contrast, off Reunion Island (Western Indian Ocean), Jaquemet et al. (2004) reported that tuna were the primary mediators for foraging shearwaters, terns and noddies; however, dolphins were the subsurface predators most commonly associated with tropicbirds. These results highlight the value of comparative regional and local studies of seabird and subsurface-predator assemblages within distinct geographic and oceanographic settings.

Documenting whether these foraging associations happen more often than would be expected by chance alone, if these seabirds and subsurface predator were randomly distributed across all schools, uncovers subtle but critical aspects of this ecological phenomenon (Au \& Pitman 1986, Pitman \& Ballance 1992, Jaquemet et al. 2004). Characterizing such preferences is an important component in assessing the strength of these ecological relationships and predicting whether cascading effects, as opposed to behavioral switching, would be likely in response to changes in the abundance of the dominant subsurface predator(s).

The present study expands the research of Harrison \& Seki (1987), who characterized the seabirdsubsurface-predator associations during the 1980s in Hawaii, but did not address these patterns statistically. Furthermore, a regime shift in the pelagic ecosystem of the Central Pacific Gyre (characterized by increased salinity, decreased sea-surface temperature and primary productivity, a shift in the composition of phytoplankton, and decreased reproductive successes of seabirds and monk seals) occurred after their study was conducted (Polovina \& Haight 1999, Karl et al. 2001). To explore whether the subsurface predator community has changed since this regime shift took place, we compare the structure of this assemblage determined from our study (2000s) and during the 1950s and 1960s using the data of Harrison \& Seki (1987).

\section{MATERIALS AND METHODS}

Surveys. At-sea surveys were conducted in summer and fall, June to November of 2000, 2001, and 2003, opportunistically aboard commercial and recreational fishing vessels around the island of Oahu, Hawaii. Eighteen trips were conducted (Fig. 1) for a total of 168 daytime survey hours. Most (14/18 or $77.8 \%$ ) trips were conducted aboard a commercial vessel targeting skipjack tuna. Surveys were non-random; they targeted specific fishing areas known for higher densities of fish and seabirds, and deliberately sought out fishseabird aggregations. Fishing effort occasionally targeted fish aggregation devices (FADs) but predominantly focused on free-ranging schools located by the presence of associated seabirds. When individuals or flocks (defined as 2 or more individuals) of foraging seabirds were observed either by A. J. Hebshi or the fishers, the vessel was directed towards the individual or flock. All foraging seabirds were counted and identified to species, and the identity of the subsurface predators, if present, was determined either through their capture or visual observations at the surface when no catches were made. The number and estimated mass of the fish harvested per school were determined when the fish were brought on deck, and the number of odontocetes per pod was estimated from surface observations.

Occasionally, schools were in close proximity with each other in time and space. If these schools consisted of different species or size classes of subsurface preda- 


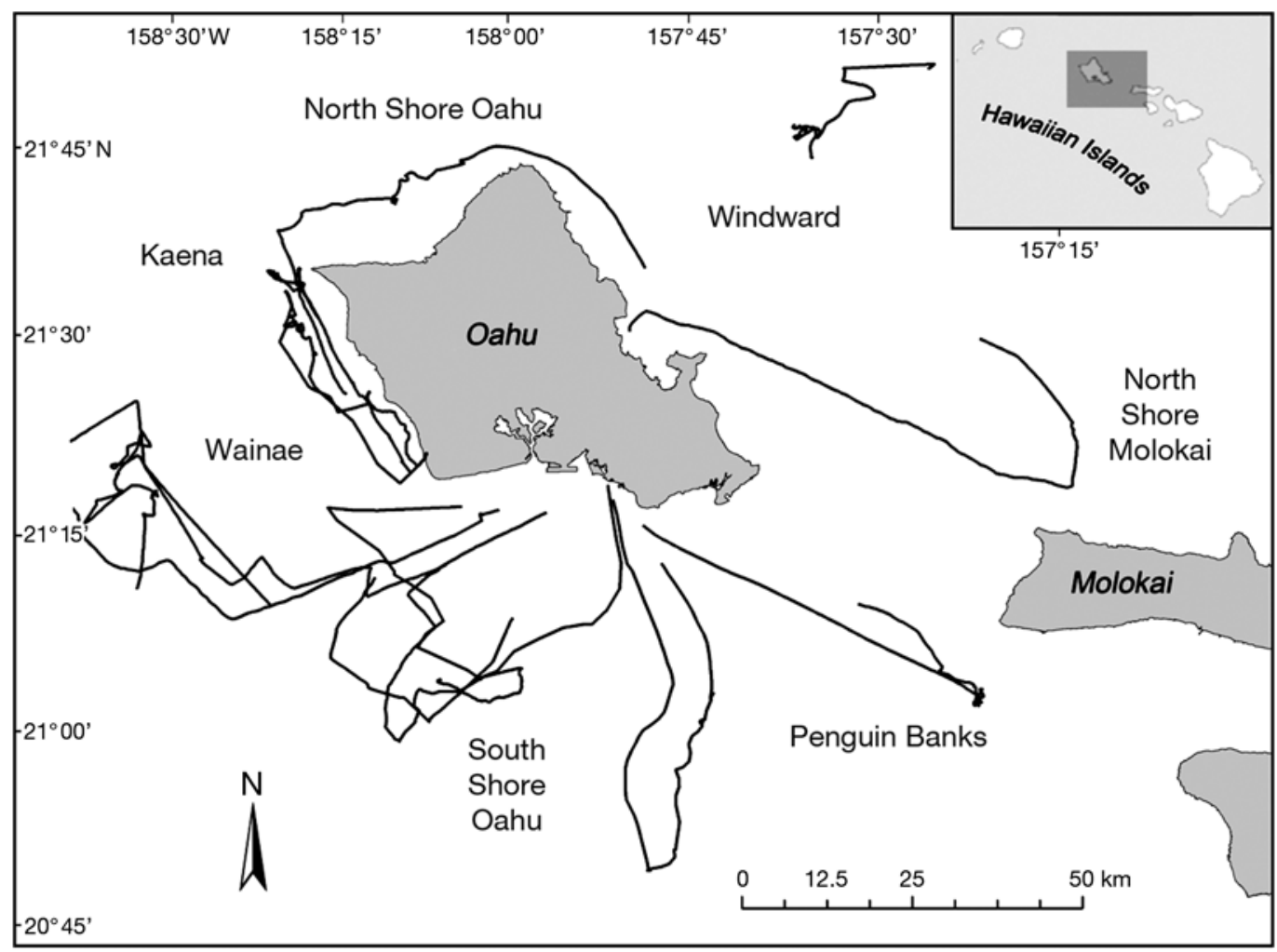

Fig. 1. Tracklines of at-sea surveys around Oahu, Hawaii, USA

tors (size class was nearly uniform within all schools), they were considered to be distinct sightings. When no such determination could be made, the observations were pooled and the largest number of individuals recorded for each seabird species was used for any subsequent analyses.

Species-specific patterns. There were sufficient numbers of observations ( $\mathrm{n}>30$ feeding flocks per event) for 3 seabird species - wedge-tailed shearwater, brown noddy Anous stolidus, and red-footed booby Sula sula-to perform univariate statistical tests to investigate whether these species associated with particular types of subsurface predators beyond what would be expected if the birds were distributed randomly across all schools. Because there were few observations of non-tuna subsurface predators, mahimahi and odontocete schools were lumped into a single functional group and compared with the observations of tuna schools. This dichotomous comparison is biologically justifiable due to the substantial difference in prey size (a key variable in seabird niche partitioning; Harrison et al. 1983) between tuna and the other predators (Roger 1994, Robertson \& Chivers 1997 , Santos \& Haimovici 2001, Olson \& Galván-Magaña 2002, Ménard et al. 2006). For each of the 3 species of birds, means and medians tests were used to determine whether the average number of individuals per flock was significantly different between the 2 subsurface predator groups. Contingency tests $\left(\chi^{2}\right)$ were used to detect if the bird species were associated with either group of subsurface predator disproportionately from what would be expected by chance.

Seabird assemblages. A multivariate test (non-metric multidimensional scaling, NMDS) was used to compare seabird assemblages among different subsurfacepredator types (PC-ORD; McCune \& Mefford 1999). NMDS is ideal for characterizing the distributions of patchy organisms because it does not impose any assumptions on the shape of the underlying habitatwildlife relationships. Furthermore, NMDS does not assemble discrete groupings of species or samples, but plots them along a multidimensional continuum representing combinations of the explanatory variables. The species and samples from similar habitats are thus plotted closer together in multivariate space (Kenkel \& Orloci 1986). This analytical technique has been used previously to characterize the structure of seabird assemblages and their habitat associations (Smith \& Hyrenbach 2003, Hyrenbach et al. 2007).

The NMDS analysis relied on a similarity matrix created using the Sorensen (Bray-Curtis) index from the raw seabird counts and 13 explanatory variables describing the type of fishing (commercial vs. sport), the type of subsurface predators (skipjack tuna, mahi- 
mahi, spotted dolphin, false killer whale, yellowfin tuna, unknown), and the geographic location around Oahu (Waianae, Penguin Bank, Kaena Point, other). Only those locations contributing at least $10 \%$ ( 7 or more) observations were considered in the analysis.

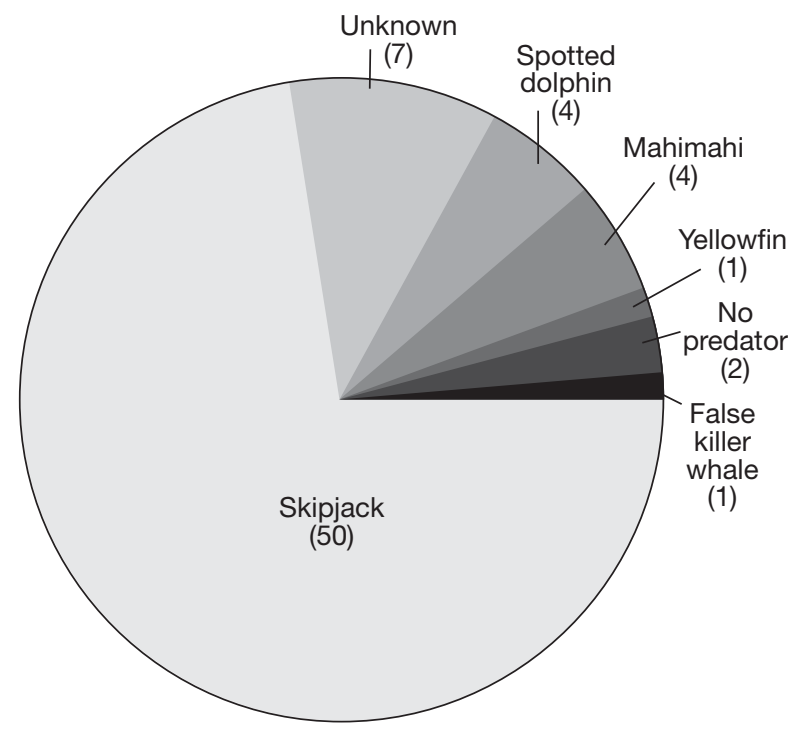

Fig. 2. Relative abundances of subsurface predators associated with foraging seabirds ( $\mathrm{n}=69$ schools). See Table 1 for scientific names

\section{RESULTS}

\section{Surveys}

A total of 69 independent seabird foraging observations were recorded. The presence and identity of subsurface predators were not ascertained in 7 (10.5\%) of the schools. In two of the remaining 62 observations (2.9\% of total), no subsurface predators appeared to be present. These were short-lived $(<10 \mathrm{~s})$ feeding events, after which the birds quickly dispersed from the site, suggesting an absence of subsurface predators. Thus, for the subsequent analyses we considered a sample size of 62 seabird foraging observations, 60 of which involved subsurface predators.

While skipjack tuna were the predominant associated subsurface predator, 4 other species were involved in feeding associations with seabirds: mahimahi Coryphaena hippurus, false killer whale Pseudorca crassidens, spotted dolphin, and yellowfin tuna (Fig. 2). These 5 species of subsurface predators were widely distributed across the study area (Fig. 3), even though only skipjack were captured north of the island. There was a significant difference in the occurrence (presence or absence) of skipjack as a function of fishing trip type (commercial vs. recreational) $\left(\chi^{2}=17.2, \mathrm{df}=1, \mathrm{p}<\right.$ 0.0005) (Fig. 4) because recreational boats targeted

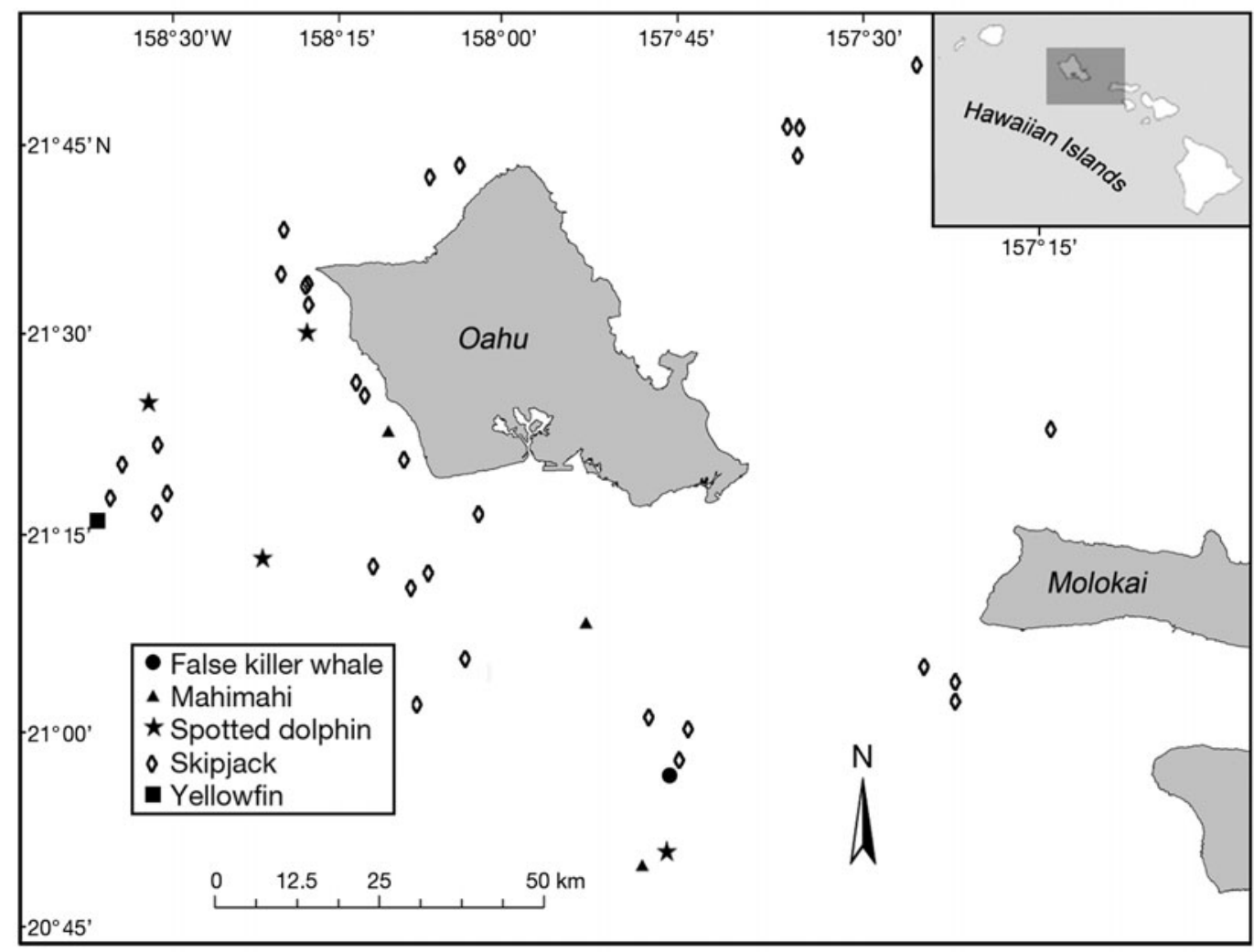

Fig. 3. Geographic locations of seabird flocks associated with subsurface-predator schools 


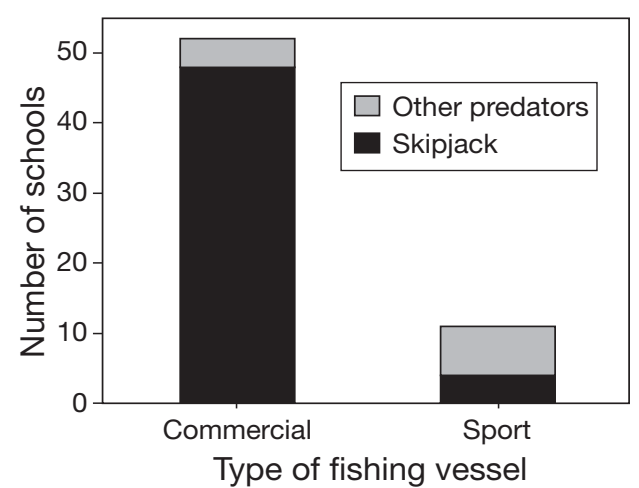

Fig. 4. Composition of subsurface-predator schools observed as a function of fishing-vessel type

logs and buoys where mahimahi were more likely to be found. Schools were typically larger for the tuna than for the odontocetes and the mahimahi. In those instances when nearly the entire tuna school was harvested $(\mathrm{n}=13)$, thus allowing for a minimum school-size estimation, $204 \pm 182$ tuna (mean \pm SD) were harvested. In contrast, the mahimahi schools $(\bar{x}=4.75, \mathrm{n}=4$, maximum $=11)$ and odontocete pods $(\bar{x}=13.8, \mathrm{n}=5$, maximum $=22)$ encountered were substantially smaller. In the 13 harvested tuna schools, only 2 contained mixed species. Skipjack comprised $>99 \%$ of these 2 schools, with yellowfin tuna and rainbow runners Elagatis bipinnulata present in very small numbers.

Twelve species of foraging seabirds (5508 individuals) were observed (Fig. 5), of which $75 \%$ were wedge-tailed shearwaters, the most abundant breed-

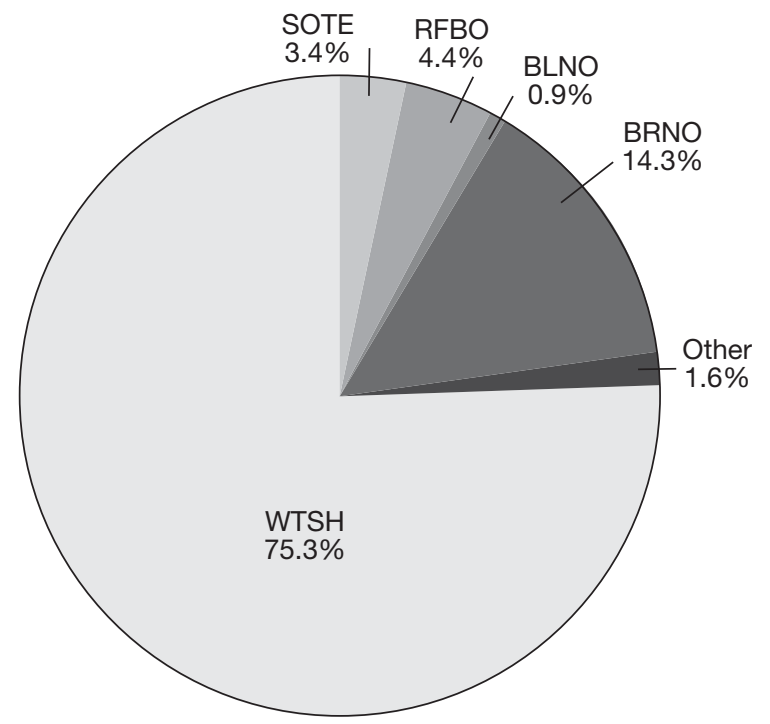

Fig. 5. Relative abundance of seabirds associated with subsurface-predator schools. WTSH = wedge-tailed shearwater, $\mathrm{BRNO}=$ brown noddy, BLNO = black noddy, RFBO = redfooted booby, SOTE = sooty tern. 'Other' includes 7 species: brown booby, white tern, great frigatebird, Newell's shearwater, pomarine jaeger, south polar skua, and sooty or shorttailed shearwaters. See Table 1 for scientific names

ing seabird in the Hawaiian Archipelago during summer and fall (Harrison et al. 1984, Spear et al. 1999). When we considered the 62 observations where the presence or absence of subsurface predators was ascertained, almost all $(99.8 \%)$ of the foraging birds were associated with subsurface predators. In particular, the vast majority $(96.0 \%)$ of these birds were associated with skipjack tuna (Table 1).

Table 1. Numbers of observed individuals of each seabird species as a function of subsurface-predator type. Values in parentheses indicate the number of schools of subsurface predator in which at least 1 individual of a given seabird species was observed. Skipjack $=$ Katsuwonus pelamis; yellowfin = Thunnus albacares; spotted dolphin = Stenella attenuata mahimahi = Coryphaena hippurus; false killer whale $=$ Pseudorca crassidens

\begin{tabular}{|c|c|c|c|c|c|c|c|c|}
\hline & & $\begin{array}{l}\text { Skipjack } \\
(50)\end{array}$ & $\begin{array}{l}\text { Yellowfin } \\
\text { (1) }\end{array}$ & $\begin{array}{c}\text { Spotted } \\
\text { dolphin } \\
\text { (4) }\end{array}$ & $\begin{array}{c}\text { Mahimahi } \\
\text { (4) }\end{array}$ & $\begin{array}{l}\text { Unknown } \\
\qquad(7)\end{array}$ & $\begin{array}{c}\text { False } \\
\text { killer whale } \\
\text { (1) }\end{array}$ & $\begin{array}{c}\text { No } \\
\text { predator } \\
(2)\end{array}$ \\
\hline Puffinus pacificus & Wedge-tailed shearwater & 3918 (49) & $60(1)$ & $71(4)$ & $4(3)$ & $80(7)$ & $5(1)$ & $12(2)$ \\
\hline Anous stolidus & Brown noddy & $730(27)$ & 0 & 0 & 0 & $58(5)$ & 0 & 0 \\
\hline Sula sula & Red-footed booby & $189(32)$ & $4(1)$ & $22(4)$ & $12(2)$ & $12(6)$ & $5(1)$ & 0 \\
\hline Anous minutus & Black noddy & $50(11)$ & 0 & 0 & 0 & $2(1)$ & 0 & 0 \\
\hline Sula leucogaster & Brown booby & $23(11)$ & 0 & $6(2)$ & $1(1)$ & 0 & 0 & 0 \\
\hline Gygis alba & White tern & $28(11)$ & 0 & $1(1)$ & $2(1)$ & $3(1)$ & 0 & 0 \\
\hline Sterna fuscata & Sooty tern & $166(9)$ & 0 & 0 & 0 & $19(3)$ & 0 & 0 \\
\hline Puffinus auricularis & Newell's shearwater & $6(4)$ & 0 & 0 & 0 & 0 & 0 & 0 \\
\hline Fregata minor & Great frigatebird & $6(6)$ & 0 & $1(1)$ & $4(2)$ & 0 & 0 & 0 \\
\hline Catharacta maccormicki & South polar skua & $4(4)$ & 0 & 0 & 0 & 0 & 0 & 0 \\
\hline Stercorarius pomarinus & Pomarine jaeger & $3(3)$ & 0 & 0 & 0 & 0 & 0 & 0 \\
\hline $\begin{array}{l}\text { Puffinus griseus or } \\
\text { P. tenuirostris }\end{array}$ & $\begin{array}{l}\text { Sooty or short-tailed } \\
\text { shearwaters }\end{array}$ & $1(1)$ & 0 & 0 & 0 & 0 & 0 & 0 \\
\hline
\end{tabular}




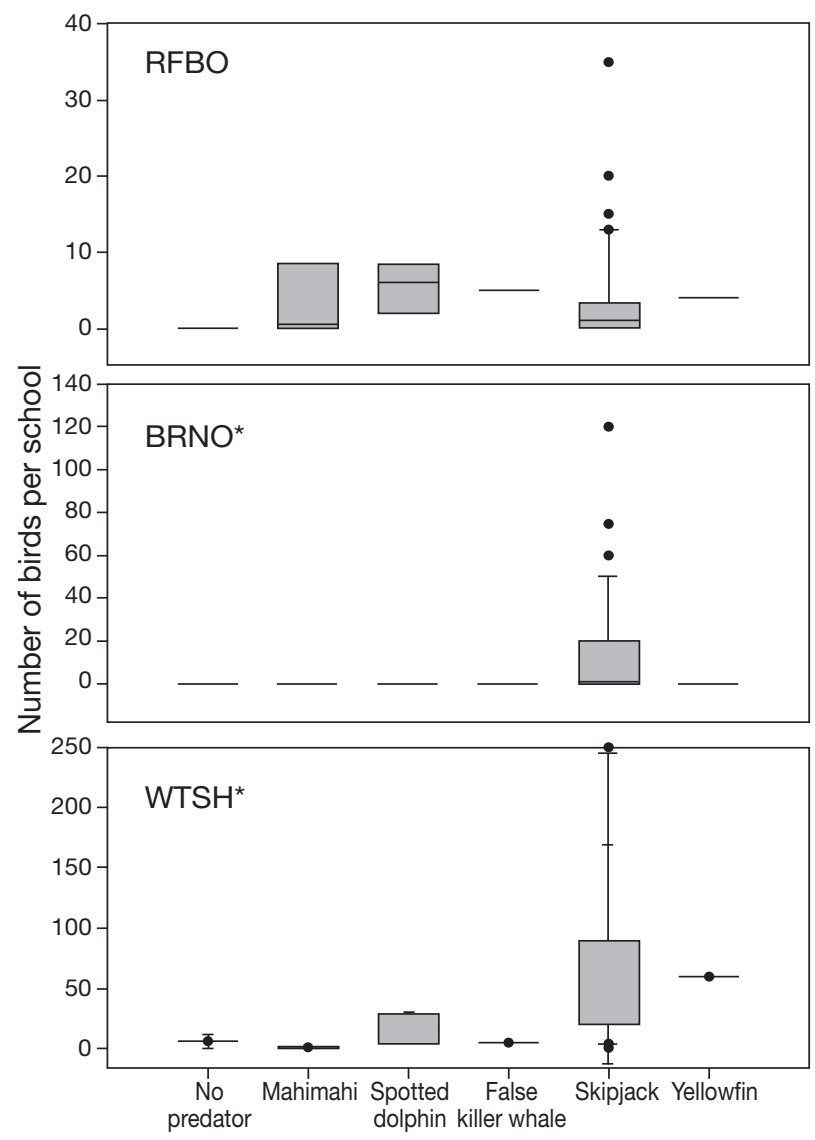

Fig. 6. Sula sula (red-footed booby, RFBO), Anous stolidis (brown noddy, BRNO), and Puffinus pacificus (wedge-tailed shearwater, WTSH). Boxplots showing the medians, quartiles, $95 \%$ bars, and outliers of the numbers of 3 focal seabird species as a function of subsurface-predator type. * Significant differences at the $\mathrm{p}<0.05$ level in the average number of birds per school over tuna vs. non-tuna species

\section{Species-specific patterns}

For 3 seabird species (wedge-tailed shearwater, brown noddy, red-footed booby), numbers of feeding events were large enough to conduct univariate tests. Non-parametric tests were used to test differences in the median number of birds per school as a function of subsurface-predator type for the first 2 species, because they did not meet the required assumption of equal variances. A Mann-Whitney test was performed for the wedge-tailed shearwater, and a sign test was performed for the brown noddy due to the large number of null values. A parametric $t$-test was used to detect differences in the mean number of redfooted boobies across different subsurface-predator schools.

There was a significant difference in the median number of foraging wedge-tailed shearwaters as a function of subsurface-predator type. Higher numbers of shearwaters foraged over tuna (skipjack and yellowfin) than over the other predators combined (MannWhitney $U=1543.5$, df $=1, \mathrm{p}=0.0009$ ) (Fig. 6). However, the presence/absence data revealed a nonsignificant result $\left(\chi^{2}=1.988\right.$, df $\left.=1,0.25>p>0.10\right)$, with no difference in the proportion of tuna schools and non-tuna schools attended by wedge-tailed shearwaters, suggesting that members of this species are not limited to foraging over tuna despite their larger number of individuals associated with these predators.

All the foraging brown noddies recorded during the present study were observed over tuna schools. Thus, there was a significant difference in the median number of individuals over tuna schools versus non-tuna schools (sign test: $\chi^{2}=10.16$, df $=1 ; p=0.001$ ) (Fig. 6). The proportion of tuna schools attended by brown noddies was higher than would be expected if these birds had foraged randomly across subsurface predator types $\left(\chi^{2}=8.663, \mathrm{df}=1, \mathrm{p}=0.013,0.01<\mathrm{p}<0.025\right)$.

There was no significant difference in the mean number of red-footed boobies as a function of subsurface predator type (tuna vs. non-tuna) $(t=0.77, \mathrm{df}=11$, $\mathrm{p}=0.455$ ) (Fig. 6). Moreover, there was no significant difference among the proportions of subsurfacepredator schools associated with boobies $\left(\chi^{2}=3.088\right.$, $\mathrm{df}=1, \mathrm{p}=0.214,0.10<\mathrm{p}<0.25)$.

\section{Seabird assemblages}

The multivariate NMDS analysis identified 2 axes with high $(99.3 \%)$ orthogonality ( $\mathrm{r}=-0.082)$, which best described the seabird community structure and explained $67.9 \%$ of the cumulative observed variance (axis 1: $\mathrm{R}^{2}=0.502$; axis $2: \mathrm{R}^{2}=0.178$ ) (Fig. 7). The stress of the best-fit NMDS was 17.873, suggesting that the performance of the test was fair (McCune \& Grace 2002).

The non-parametric (Kendall) cross-correlations between the explanatory variables and the 2 significant axes revealed that the seabird community structure was influenced primarily by the presence of wedgetailed shearwaters and brown noddies, the 2 most abundant seabird species, with significant correlations with both axes (Table 2). These results suggest that the first axis captured the differences between commercial and sport fishing vessels, while the second axis captured the variability across geographic locations. This analysis also revealed significant Kendall correlations with the first axis for 2 subsurface predators: mahimahi $(\mathrm{n}=67, \mathrm{tau}=+0.281,0.05<\mathrm{p}<0.005)$ and skipjack $(\mathrm{n}=$ 67 , tau $=-0.452,0.001<\mathrm{p}<0.005$ ). These results reinforced the observation from the univariate analyses that wedge-tailed shearwaters and brown noddies tend to forage in greater proportion over skipjack tuna 


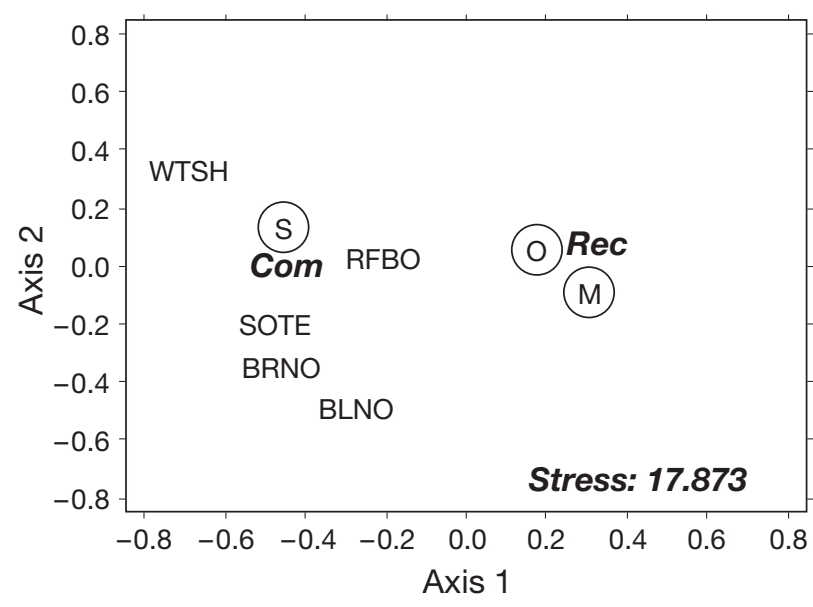

Fig. 7. NMDS plot showing 2-dimensional distances among the 5 most abundant seabirds (WTSH = wedge-tailed shearwater, $\mathrm{SOTE}=$ sooty tern, $\mathrm{RFBO}=$ red-footed booby, BLNO = black noddy, BRNO = brown noddy), 2 fishery types (commercial [Com] vs. recreational [Rec]), and 3 subsurface-predator types $(\mathrm{M}=$ mahimahi, $\mathrm{O}=$ odontocete, $\mathrm{S}=$ skipjack $)$

Table 2. Kendall correlations with first and second ordination axes $(\mathrm{n}=67)$. Significant values are in bold. Significance levels are: $\alpha_{0.005}=0.341, \alpha_{0.05}=0.241$. See Table 1 for scientific names of seabird species and predator type

\begin{tabular}{|c|c|c|}
\hline & $\begin{array}{c}\text { Axis } 1 \\
\text { tau }\end{array}$ & $\begin{array}{c}\text { Axis } 2 \\
\text { tau }\end{array}$ \\
\hline \multicolumn{3}{|l|}{ Seabird species } \\
\hline Wedge-tailed sheawater & -0.779 & 0.427 \\
\hline Brown noddy & -0.242 & -0.537 \\
\hline Black noddy & -0.168 & -0.103 \\
\hline Brown booby & -0.037 & -0.144 \\
\hline Red-footed booby & -0.093 & -0.017 \\
\hline Sooty tern & -0.106 & -0.329 \\
\hline White tern & -0.007 & 0.119 \\
\hline $\begin{array}{l}\text { Sooty or short-tailed } \\
\text { shearwaters }\end{array}$ & -0.089 & -0.147 \\
\hline Pomarine jaeger & -0.104 & -0.098 \\
\hline South polar skua & -0.163 & 0.201 \\
\hline Newell's shearwater & -0.237 & 0.237 \\
\hline Great frigatebird & 0.059 & 0.091 \\
\hline \multicolumn{3}{|l|}{ Vessel type } \\
\hline Sport & 0.351 & -0.011 \\
\hline Commercial & -0.351 & 0.011 \\
\hline \multicolumn{3}{|l|}{ Location } \\
\hline Waianae & -0.078 & 0.315 \\
\hline Penguin Banks & 0.050 & 0.017 \\
\hline Kaena & -0.006 & -0.125 \\
\hline Windward & -0.008 & -0.288 \\
\hline Other & 0.080 & -0.125 \\
\hline \multicolumn{3}{|l|}{ Predator type } \\
\hline Spotted dolphin & 0.185 & 0.040 \\
\hline Mahimahi & 0.281 & -0.070 \\
\hline False killer whale & 0.141 & -0.016 \\
\hline Skipjack & -0.452 & 0.134 \\
\hline Yellowfin & -0.037 & 0.094 \\
\hline Unknown & 0.241 & -0.199 \\
\hline
\end{tabular}

schools. The sooty tern was the only species significantly correlated with the second axis $(\mathrm{n}=67$, tau $=$ $-0.329,0.05<\mathrm{p}<0.005)$.

\section{Long-term changes in the subsurface-predator community}

In the present study, we found no evidence of qualitative changes in the seabird-subsurface-predator associations as a result of a regime shift in the Central North Pacific Gyre in the 1980s. Harrison \& Seki (1987) concluded that skipjack were the dominant predators over which seabirds feed in waters around the main Hawaiian Islands, with $75 \%$ of the 681 bird flocks observed on cruises in the 1950s and 1960s being associated with schools of this predator. This historical result is comparable with the proportion of $81 \%$ (50/62) documented in the present study.

\section{DISCUSSION}

Our research corroborates previous assessments of the importance of subsurface predators to the foraging ecology of many species of tropical seabirds (Au \& Pitman 1986, Harrison \& Seki 1987, Jaquemet et al. 2004), and provides new information about seabird associations with specific subsurface predators within the commercial and sport fishing grounds surrounding the island of Oahu. In this area, at least 2 species of seabirds forage in association with tuna schools (primarily skipjack) disproportionately more frequently than would be expected if the birds were randomly distributed across all types of predator schools. We hypothesize that tuna schools are the most profitable for seabirds, particularly for the smaller species, for 2 reasons: (1) the larger size and greater persistence of tuna schools increases the duration of the foraging opportunity, and (2) these schools provide prey of greater suitability (i.e. size class, species, quantity).

Although we were unable to determine whether these larger foraging schools of subsurface predators were more visible and long-lasting, Au \& Pitman (1986) found that the number of seabirds in a flock was positively correlated with the size of the subsurface predator school. We hypothesize that larger schools are indicative of larger prey concentrations and provide a larger surface area for a greater number of seabirds to access these prey resources.

Differences in prey types may also be driving the observed segregation of seabird species across subsurface-predator schools. Because mahimahi and odontocetes generally feed on larger prey than do the tuna (Roger 1994, Robertson \& Chivers 1997, Santos \& Hai- 
movici 2001, Olson \& Galván-Magaña 2002, Ménard et al. 2006), these larger prey may be outside of the size range suitable for the smaller birds, particularly the terns and to a lesser extent the shearwaters. For example, mahimahi stomach contents from the ETP revealed an average prey length of $160.0 \mathrm{~mm}$ (Olson \& Galván-Magaña 2002), whereas yellowfin tuna stomach contents from the same geographic area contained an average prey length of $38.2 \mathrm{~mm}$ (Ménard et al. 2006). A comprehensive diet study of Hawaiian seabirds revealed that different species feed on distinct prey size ranges: up to $145 \mathrm{~mm}$ for wedge-tailed shearwaters, $93 \mathrm{~mm}$ for brown noddies, and $200 \mathrm{~mm}$ for redfooted boobies (Harrison et al. 1983). Therefore, the shearwaters and noddies-but not the boobiesappear to be morphologically constrained from consuming even the average prey size of mahimahi. Because tropical seabirds are fairly diverse in their prey taken within their preferred size class (Harrison et al. 1983), prey taxonomy by itself probably has no bearing on seabird-subsurface-predator associations. Rather, any apparent taxonomic preferences are probably residual effects from feeding behaviors of the associated subsurface predators (Spear et al. 2007).

\section{Potential biases and limitations of this study}

The majority of the seabird interactions with subsurface predators observed in the present study involved skipjack tuna. Due to the low densities of seabird flocks in tropical waters, we resorted to using fishing vessels to locate subsurface predators rather than using random survey tracks. This approach has been used previously in other regions to facilitate otherwise logistically difficult and expensive surveys (Jaquemet et al. 2004). Because the sampling was not random, however, these data may not accurately reflect the actual relative proportions of subsurface predator schools in the waters around Oahu. In fact, the different proportions of school types from commercial versus sport vessels highlights this lack of randomness. Nevertheless, it is likely that the observations from commercial vessels, which were dominated by skipjack tuna, were more akin to a random sampling. Conversely, the sport-fishing vessels yielded a somewhat biased perspective by targeting FADs and other floating objects where mahimahi aggregate (Kojima 1956).

Our observations may also have been biased towards sampling seabirds associated with subsurface predators, while other foraging methods may have been underrepresented. First, night feeding (which may or may not involve the participation of subsurface predators) is supported by direct observations in wedgetailed shearwaters and sooty terns (Gould 1967), and by evidence that wedge-tailed shearwater colony attendance during full moon nights is lower than during new moon nights (Shallenberger 1973). However, the greater numbers of birds attending the colonies at night versus during the day underscores the notion that nocturnal foraging is probably a minor contributor to overall feeding in tropical 'tuna birds' (Whittow 1997, Gauger 1999, Schreiber et al. 2002).

Second, the present study likely underestimated the overall incidence of solo or small-flock feeding in the absence of subsurface predators on surface-dwelling prey. This behavior is more transient and therefore less conspicuous and harder to detect at sea. For instance, only two out of the 62 feeding events characterized during the present study were of this type. However, previous research has shown the rarity of solo or smallflock feeding for some of these species. In central Pacific cruises performed in the 1960s, King (1974) and Gould (1974) reported that 93\% of all wedge-tailed shearwaters and $77 \%$ of all sooty terns were observed feeding in mixed-species flocks. These data were collected along transect lines and limited to a distance of no greater than 0.75 miles $(1.2 \mathrm{~km})$, a range explicitly chosen by the researchers to exclude birds whose behavior could not be determined (Gould 1974).

Finally, because these data have a seasonal bias (summer and fall) and a limited geographic scope (waters around Oahu), they do not represent the entire Hawaiian seabird community. In particular, sooty terns, which breed in spring and early summer, were not recorded in large numbers despite their large breeding densities around Oahu (Harrison et al. 1984).

\section{Implications for fishery management and seabird population health}

Despite the limitations and potential biases of the present study, it appears that skipjack tuna are important mediators of food availability for several species of seabirds around Oahu. Skipjack comprise the bulk of the subsurface predators involved in foraging associations with seabirds, and at least 2 seabird species forage in association with tuna schools in greater numbers than would be expected by chance alone. These observations are in line with previous observations on the relative importance of skipjack to seabirds in Hawaiian waters (Harrison \& Seki 1987). The qualitative nature of this relationship appears stable despite an oceanographic regime shift and long-term climate change. Despite evidence that skipjack biomass is increasing on a global scale (Sibert et al. 2006), localized depletion due to heavy fishing and redistribution or declines in abundance due to large-scale inter-annual and longer-term oceanographic fluctuations (e.g. Lehodey et al. 1997, 
Karl et al. 2001, Polovina 2005) could reduce skipjack abundance within the foraging range of seabirds, especially during the breeding season when these centralplace foragers are constrained to return to their colonies. For instance, Boggs \& Kikkawa (1993) documented a decline in the catch per unit effort of skipjack tuna around Hawaii through the 1970s. Moreover, ecosystem-level modeling has shown that substantial increases in fishing pressure on yellowfin tuna could, through a complex community-level response, lead to a decline in skipjack abundance and an increase in mahimahi (Hinke et al. 2004).

Our empirical observations and the modeling results from Hinke et al. (2004) have important implications for the development of ecosystem-level fishery practices that incorporate an understanding of the ecological relationships and the consequences of oceanographic variability and management actions. In particular, our research suggests that seabirds may not readily switch to using other subsurface predators such as mahimahi, in the event of redistributions or population declines in skipjack tuna. Therefore, the heavy reliance of seabirds on tuna may affect their ability to successfully find prey and maintain healthy populations. Based on the particular characteristics of the tuna schools and their prey, we anticipate that the smaller-sized seabirds - shearwaters, terns, and noddies - would experience reduced foraging opportunities. For this reason, we concur with the warning of other authors (e.g. University of Alaska Sea Grant College 1999, Yaffee 1999, Link 2002, Hinke et al. 2004, Worm et al. 2006) against the reliance on stockviability management as the sole driver of our fisherymanagement policies. Instead, we advocate the adoption of broader ecosystem-based management considerations, including the ecological interactions between the target and non-target species.

Acknowledgements. This research would not have been possible without the permission from the Nisei, Mazel Tov, and Force Cat owners, captains, and crew to conduct observations aboard their fishing vessels. D. G. Itano, K. Bourdon, and A. T. Handler were instrumental in securing access to the vessels. We thank J. C. Drazen for a critical review of an earlier draft of this manuscript, and L. T. Ballance and 2 anonymous reviewers for strengthening the manuscript in its final form.

\section{LITERATURE CITED}

Ashmole NP (1971) Seabird ecology and the marine environment. In: Farner DS, King DR, Parkes KC (eds) Avian biology, Vol 1. Academic Press, New York, p 223-286

Au DW (1991) Polyspecific nature of tuna schools: sharks, dolphin, and seabird associates. Fish Bull 89:343-354

Au DW, Pitman RL (1986) Seabird interactions with dolphins and tuna in the eastern tropical Pacific. Condor 88: $304-317$
Au DW, Pitman RL (1988) Seabird relationships with tropical tunas and dolphins. In: Burger J (ed) Seabirds and other marine vertebrates. Columbia University Press, New York, p 174-209

Ballance LT, Pitman RL, Reilly SB (1997) Seabird community structure along a productivity gradient: importance of competition and energetic constraint. Ecology 78:1502-1518

Boggs CH, Kikkawa BS (1993) The development and decline of Hawaii's skipjack tuna fishery. Mar Fish Rev 55:61-68

Clua E, Grosvalet R (2001) Mixed-species feeding aggregations of dolphins, large tunas and seabirds in the Azores. Aquat Living Resour 14:11-18

Estes JA, Danner EM, Doak DF, Konar B and others (2004) Complex trophic interactions in kelp forest ecosystems. Bull Mar Sci 74:621-638

FAO (Food and Agriculture Organization of the United Nations) (2007) Total production 1950-2005. FISHSTAT Plus - universal software for fishery statistical time series. FAO Fisheries and Aquaculture Information and Statistics Service, Rome. Available at: www.fao.org/fishery/statistics/ software/fishstat

Gauger VH (1999) Black noddy. In: Poole A (ed) The birds of North America online database. Cornell Laboratory of Ornithology, Ithaca. Available at: http://bna.birds.cornell. edu.eres.library.manoa.hawaii.edu/BNA/accout/Black_ Noddy/

Gould PJ (1967) Nocturnal feeding of Sterna fuscata and Puffinus pacificus. Condor 69:529

Gould PJ (1974) Sooty tern (Sterna fuscata). In: King WB (ed) Pelagic studies of seabirds in the central and eastern Pacific Ocean. Smithson Contrib Zool 158:6-52

Grünbaum D, Veit RR (2003) Black-browed albatrosses foraging on Antarctic krill: density-dependence through local enhancement? Ecology 84:3265-3275

Harrison CS, Seki MP (1987) Trophic relationships among tropical seabirds at the Hawaiian Islands. In: Croxall JP (ed) Seabirds: feeding ecology and role in marine ecosystems. Cambridge University Press, Cambridge, p 305-326

Harrison CS, Hida TH, Seki MP (1983) Hawaiian seabird feeding ecology. Wildl Monogr 85:1-71

Harrison CS, Naughton MB, Fefer SI (1984) The status and conservation of seabirds in the Hawaiian Archipelago and Johnston Atoll. In: Croxall JP, Evans PGH, Schreiber RW (eds) Status and conservation of the world's seabirds. International Council for Bird Preservation (ICBP), Cambridge, p 513-526

Hinke JT, Kaplan IC, Aydin K, Watters GM, Olson RJ, Kitchell JF (2004) Visualizing the food-web effects of fishing for tunas in the Pacific Ocean. Ecol Soc 9:10. Available at: http://www.ecologyandsociety.org/vol9/iss1/art10/

Hyrenbach KD, Veit RR, Weimerskirch H, Metzl N, Hunt GL Jr (2007) Community structure across a large-scale ocean productivity gradient: marine bird assemblages of the southern Indian Ocean. Deep-Sea Res I 54:1129-1145

> Jaquemet S, LeCorre M, Weimerskirch H (2004) Seabird community structure in a coastal tropical environment: importance of natural factors and fish aggregating devices (FADs). Mar Ecol Prog Ser 268:281-292

Karl DM, Bidigare RR, Letelier RM (2001) Long-term changes in plankton community structure and productivity in the North Pacific Subtropical Gyre: the domain shift hypothesis. Deep-Sea Res II 48:1449-1470

Kenkel NC, Orloci L (1986) Applying metric and nonmetric multidimensional scaling to ecological studies: some new results. Ecology 67:919-923

King WB (1974) Wedge-tailed shearwater. In: King WB (ed) Pelagic studies of seabirds in the central and eastern 
Pacific Ocean. Smithson Contrib Zool 158:53-95

Kitchell JF, Boggs CH, He X, Walters CJ (1999) Keystone predators in the central Pacific. In: Ecosystem approaches for fisheries management. Report no. AK-SG-99-01. University of Alaska Sea Grant College, Fairbanks, AK, p 665-684. Available at: http://seagrant.uaf.edu/bookstore/ pubs/AK-SG-99-01-a.pdf

Kojima S (1956) Fishing for dolphins in the western part of the Japan Sea. II. Why do the fish take shelter under floating materials? Bull Jpn Soc Sci Fish 21:1049-1052

Krebs CJ (1972) Ecology: the experimental analysis of distribution and abundance. Harper \& Row, New York

Lehodey P, Bertignac M, Hampton J, Lewis A, Picaut J (1997) El Niño Southern Oscillation and tuna in the western Pacific. Nature 389:715-718

Link JS (2002) What does ecosystem-based fisheries management mean? Fisheries 27:18-21

McCune B, Grace JB (2002) Analysis of ecological communities. MJM Publishers, Gleneden Beach, OR

McCune B, Mefford MJ (1999) PC-ORD: multivariate analysis of ecological data (version 4). MjM Software Design, Gleneden Beach, OR

Ménard FC, Labrune C, Shin YJ, Asine AS, Bard FX (2006) Opportunistic predation in tuna: a size-based approach. Mar Ecol Prog Ser 323:223-231

Myers RA, Baum JK, Shepherd TD, Powers SP, Peterson CH (2007) Cascading effects of the loss of apex predatory sharks from a coastal ocean. Science 315:1846-1850

Olson RJ, Galván-Magaña F (2002) Food habits and consumption rates of common dolphinfish (Coryphaena hippurus) in the eastern Pacific Ocean. Fish Bull 100:279-298

Pitman RL (1993) Seabird associations with marine turtles in the eastern Pacific Ocean. Colon Waterbirds 16:194-201

Pitman RL, Ballance LT (1992) Parkinson petrel distribution and foraging ecology in the eastern Pacific-aspects of an exclusive feeding relationship with dolphins. Condor 94:825-835

Polovina JJ (2005) Climate variation, regime shifts, and implications for sustainable fisheries. Bull Mar Sci 76: 233-244

Polovina JJ, Haight WR (1999) Climate variation, ecosystem dynamics, and fisheries management in the Northwestern Hawaiian Islands. In: Ecosystem approaches for fisheries management. Report no. AK-SG-99-01. University of Alaska Sea Grant College, Fairbanks, AK, p 23-32. Available at: http://seagrant.uaf.edu/bookstore/pubs/AK-SG99-01-a.pdf

Potier M, Marsac F, Cherel Y, Lucas V, Sabatié R, Maury O, Ménard F (2007) Forage fauna in the diet of three large

Editorial responsibility: William Sydeman,

Petaluma, California, USA pelagic fishes (lancetfish, swordfish and yellowfin tuna) in the western equatorial Indian Ocean. Fish Res 83:60-72

Robertson KM, Chivers SJ (1997) Prey occurrence in pantropical spotted dolphins, Stenella attenuate, from the eastern tropical Pacific. Fish Bull 95:334-348

Roger C (1994) Relationships among yellowfin and skipjack tuna, their prey-fish and plankton in the tropical western Indian Ocean. Fish Oceanogr 3:133-141

Santos RA, Haimovici M (2001) Cephalopods in the diet of marine mammals stranded or incidentally caught along southeastern and southern Brazil $\left(21-34^{\circ} \mathrm{S}\right)$. Fish Res 52: 99-112

Schreiber EA, Feare CJ, Harrington BA, Murray BG Jr, Robertson WB Jr, Robertson MJ, Woolfenden GE (2002) Sooty tern. In: Poole A (ed) The birds of North America online database. Cornell Laboratory of Ornithology, Ithaca. Available at: http://bna.birds.cornell.edu.eres. library.manoa.hawaii.edu/BNA/accout/Sooty_Tern/

Shallenberger RJ (1973) Breeding biology, homing behavior and communication patterns of the wedge-tailed shearwater Puffinus pacificus chlororhynchus. $\mathrm{PhD}$ dissertation, University of California, Los Angeles

Sibert J, Hampton J, Kleiber P, Maunder M (2006) Biomass, size, and trophic status of top predators in the Pacific Ocean. Science 314:1773-1776

Smith JL, Hyrenbach KD (2003) Galápagos Islands to British Columbia: seabird communities along a $9000 \mathrm{~km}$ transect from the tropical to the subarctic Eastern Pacific Ocean. Mar Ornithol 31:155-166

Spear LB, Ainley DG, Pyle P (1999) Seabirds in southeastern Hawaiian waters. West Birds 30:1-32

Spear LB, Ainley DG, Walker WA (2007) Foraging dynamics of seabirds in the eastern tropical Pacific Ocean. Stud Avian Biol 35:1-99

University of Alaska Sea Grant College (1999) Ecosystem approaches for fisheries management. Report no. AK-SG99-01. University of Alaska Sea Grant College, Fairbanks, AK. Available at: http://seagrant.uaf.edu/bookstore/pubs/ AK-SG-99-01-a.pdf

Whittow CG (1997) Wedge-tailed shearwater. In: Poole A (ed) The birds of North America online database. Cornell Laboratory of Ornithology, Ithaca. Available at: http://bna. birds.cornell.edu.eres.library.manoa.hawaii.edu/BNA/ accout/Wedge-tailed_Shearwater

- Worm B, Barbier EB, Beaumont N, Duffy JE and others (2006) Impacts of biodiversity loss on ocean ecosystem services. Science 314:787-790

Yaffee SL (1999) Three faces of ecosystem management. Conserv Biol 13:713-725

Submitted: January 28, 2008; Accepted: October 6, 2008 Proofs received from author(s): November 16, 2008 